УДК 629.04

Канд. техн. наук А.В. Донченко

(ДП «УкрНДІВ)

Cand. of techn. sciences A.V. Donchenko

\title{
СТРАТЕГІЯ РОЗВИТКУ ТРАНСПОРТНОГО МАШИНОБУДУВАННЯ ДЛЯ ЗАЛІЗНИЦЬ УКРАЇНИ
}

\author{
STRATEGY OF TRANSPORT MACHINERY FOR RAILWAYS \\ OF UKRAINE
}

\section{Представив д-р техн. наук, професор I.Е. Мартинов}

Транспорт відіграє одну з ключових ролей у стратегії розвитку держави. Стійкість економічного зростання може бути досягнута тільки при стабільній чіткій взаємодії усіх ланок, а саме виробництва рухомого складу, інфраструктури, логістичних процесів, у тому числі i перевізного процесу. В Україні транспортна діяльність робить суттєвий внесок у створення валової додаткової вартості. Згідно з даними, наведеними у роботі [1], частка валової доданої вартості становить $13 \%$, а вартість основних засобів виробництва - близько $35 \%$ загальної вартості потенціалу країни, середньооблікова чисельність штатних працівників галузі складає понад 935 тис. осіб. Наведені дані свідчать про нагальну необхідність проведення комплексних заходів стосовно розвитку транспортної галузі. Стратегія розвитку передбачає реалізацію цілого ряду інфраструктурних i транспортних проектів. Стратегія розвитку залізничної галузі передбачає, у першу чергу, розмежування пасажирських i вантажних залізничних маршрутів, створення та впровадження високошвидкісного руху, продовження розбудови транспортних коридорів, що забезпечать більш ефективне сполучення між Свропою та Азією через територію України.
Основним завданням сьогодення $\epsilon$ інтегрування залізничної галузі України в європейську та світову мережу. Для цього необхідним $\epsilon$ виконання вимог євростандартів, застосування електронного документообігу та електронного підпису при залізничних міжнародних і внутрішніх перевезеннях. Особливо актуальним питанням у цьому зв'язку $\epsilon$ питання модернізації залізничної галузі України 3 метою відповідності ii європейським стандартам щодо рухомого складу для експлуатації як на колії 1520 мм, так і на колії 1435 мм. Основними вимогами при цьому до рухомого складу $\epsilon$ швидкість $\mathrm{i}$ якість перевезення вантажів, особливо тих, що швидко псуються. На новий рівень необхідно піднімати вимоги щодо пасажирського рухомого складу. До основних завдань щодо рухомого складу, окрім різкого підвищення швидкості руху та комфортності, з метою збільшення його надійності та економічності і збереження, а також забезпечення безпеки руху при цьому, належать розмежування вантажного та пасажирського рухомого складу залізниць. У наш час на передній план вийшли питання оновлення рухомого складу, який знаходиться вкрай зношеному робочому стані. За даними різних офіційних джерел інформації, зношеність основних засобів досягла близько $90 \%$, а 
знос тепловозів досягає 97-99\%, електровозів понад $90 \%$, така ж зношеність і приміського рухомого складу. На рівні 85-90\% знаходиться зношеність вантажного рухомого складу. Виходячи 3 викладеного повинен відповідним чином перебудовуватися і машинобудівний комплекс України для задоволення нових потреб залізничного транспорту. Як відомо, сьогодні машинобудівна галузь для залізничного транспорту зорієнтована на експорт. Обсяги експорту рухомого складу підприємств України складають понад $80 \%$.

У машинобудівному комплексі України були зосереджені значні промислові потужності для продукції вагонобудування та тепловозобудування. Близько $60 \%$ загального обсягу виробництва вантажних вагонів в СРСР та близько $\quad 80 \%$ тепловозів поставлялось виробничим комплексом України.

Завдання галузі полягає у забезпеченні виробництва сучасного рухомого складу та іншого обладнання для залізничного транспорту та міського господарства, у тому числі в перспективі для швидкісного та високошвидкісного залізничного транспорту, модернізації інфраструктури залізниць для забезпечення швидкісного руху поїздів.

Необхідно зазначити, що як і саме збереження галузі транспортного машинобудування, так і політика в сфері управління якістю на підприємствах цієї галузі переживає етап становлення і цей процес неперервно зв'язаний зі створенням та освоєнням нової продукції.

У розвинутих країнах світу саморозвиток транспортного комплексу розвивається за такими напрямками:

- створення високими темпами нових моделей і поколінь продукції;

- ефективне застосування принципово нових машин, матеріалів, комплектуючих, технологічних систем;

- випуск конкурентоспроможної продукції, здатної задовольнити потреби секторів економіки, від яких залежить безпека держави та споживчого ринку, i одним 3 найбільших секторів, що забезпечує їхнє надійне функціонування, $\epsilon$ залізничний транспорт;

- здатність виробництва до широкого впровадження науково-технічних досягнень, високий рівень транснаціональної інтеграції науки, технологій і промислового виробництва, домінування наукоємних галузей;

- забезпечення значного рівня розвитку інформаційної, впроваджувальної, транспортної, постачально-збутової інфраструктури;

- раціональне

впровадження

ресурсозберігаючих і відновлювальних технологій;

- забезпечення високого рівня екологічної безпеки;

- досягнення оптимального співвідношення ефективного функціонування державного i приватного секторів промисловості.

Основними принципами державної політики в секторі транспортного машинобудування $\epsilon$ :

- забезпечення національних інтересів;

- соціальна та економічна спрямованість реформування транспортного машинобудування;

- поєднання державного регулювання з ринковими механізмами саморегуляції;

- програмно-цільовий підхід до вирішення завдань щодо політики транспортного машинобудування;

- поглиблення процесів інтеграції у світову економіку, насамперед євроінтеграції.

Реалізація викладених принципів полягає у створенні належних умов для розвитку сектора транспортного машинобудування на ринкових засадах 3 одночасним посиленням державного регулювання, де ринкові механізми діють неефективно. 
Передбача
забезпечити:

прискорити

та

- інституційні перетворення 3 утвердження конкурентного середовища;

- конкурентоспроможність

залізничної техніки через реалізацію іiі інноваційного шляху розвитку, формування нових технічних укладів, підтримку розвитку наукоємних виробництв;

- збільшення обсягу експорту, у першу чергу наукоємної продукції;

- провести структурну перебудову виробництва, стимулювати його оновлення, забезпечити випереджаючий розвиток широкомасштабної модернізації шляхом оновлення основних засобів транспортної галузі.

Зростаючий попит на транспортні послуги з боку вітчизняних та іноземних користувачів за даними, наведеними у роботі [1], не може бути повністю задоволений без кардинального оновлення рухомого складу. Аналіз темпів реального оновлення парку вантажних вагонів (нині інвентарний парк налічує близько 120 тис. вантажних вагонів), навіть при падінні обсягів перевезень вантажів у найближчі роки, призведе до їх дефіциту, а при збільшенні обсягів перевезень у перспективі - до невикористання потенційних можливостей, особливо щодо експортних вантажних перевезень. Так, наприклад, тільки у першому півріччі 2011 р. ДП «Свердловськантрацит» недоотримало 6650 вагонів або 15,4\% планової цифри. Внаслідок цього підприємство самостійно здійснювало ремонт вагонів і нераціонально витрачало великі обсяги матеріальних ресурсів.

За оцінками експертів, станом на кінець 2011 р. 6000 напіввагонів необхідно було замінити новими. Окрім того, значна кількість вагонів не може експлуатуватися внаслідок незадовільного технічного стану і потребує оновлення.

На підставі викладеного знаходить підтвердження вимога якомога скорішої реалізації завдань, поставлених у роботах
$[2,3]$. У цих документах були розроблені вимоги до конструкцій рухомого складу нового покоління, а саме:

- підвищення продуктивності на 18$20 \%$;

- збільшення осьового навантаження не менш ніж на 7 \%;

- зменшення питомої металоконструкції на $10 \%$;

- економія енерговитрат на

експлуатацію до $20 \%$;

- зменшення капітальних вкладень на закупівлю рухомого складу з одночасним освоєнням планових перевезень - не менш ніж на $5 \%$;

- економія експлуатаційних витрат не менш ніж на $5 \%$;

- підвищення надійності конструкцій, широке застосування технічної діагностики i неруйнівного контролю, збільшення міжремонтних пробігів і збільшення моторесурсу.

Провідними машинобудівними підприємствами України, насамперед такими, як ПАТ «Крюківський вагонобудівний завод», ПАТ «Стаханівський вагонобудівний завод», ПАТ «Дніпровагонмаш», ПАТ «Азовмаш», протягом 2009-2012 років створено конструкції вагонів, що відповідають зазначеним вимогам. Технічні характеристики вагонів нового покоління України наведені в табл. 1. Але для серійного виробництва зазначених вагонів, промисловість України повинна найближчим часом виконати роботи за такими напрямками:

- освоїти нові конструкційні сталі;

- освоїти нові ливарні сталі, які повинні мати стабільний коефіцієнт запасу міцності на втому 2,0 та зменшення маси візка на $15 \%$;

- налагодити серійний випуск вітчизняних касетних підшипників та інших конструкцій підшипників 3 аналогічними характеристиками;

- освоїти сучасне виробництво зносостійких елементів візків, фрикційних 
клинів і ковзунів з термічно обробленого високоміцнісного чавуну; виробництво поліуретанових деталей візків; виробництво зносостійких полімерних втулок важільної передачі з пробігом 800 тис. км;

- створити сучасні автозчепи, що будуть вирішувати питання різниці осей i надійності зчеплення;
- опрацювати технологію захисту від зносу тертям елементів вагона (автозчеп, хомут, клин, центруючі балочка і т. ін.);

- розробити та освоїти виробництво поглинальних апаратів; виробництво нових гальмівних систем вагонів; сімейство візків вантажних вагонів для різних типів вагонів.

Таблиця 1

\begin{tabular}{|c|c|c|c|c|c|c|c|c|}
\hline $\begin{array}{l}\text { Найменування } \\
\text { параметрів і } \\
\text { розмірність }\end{array}$ & $\begin{array}{c}\text { Напів- } \\
\text { вагон } \\
\text { ПАТ } \\
\text { «КВБЗ» }\end{array}$ & $\begin{array}{c}\text { Вагон } \\
\text { для } \\
\text { зерна } \\
\text { ПАТ } \\
\text { «КВБЗ» }\end{array}$ & $\begin{array}{c}\text { Напів- } \\
\text { вагон } \\
\text { ПАТ } \\
\text { «СВ3» }\end{array}$ & $\begin{array}{c}\text { Напів- } \\
\text { вагон } \\
\text { ПАТ } \\
\text { «Ди- } \\
\text { зель- } \\
\text { ний } \\
\text { завод» }\end{array}$ & $\begin{array}{c}\text { Напів- } \\
\text { вагон } \\
\text { ПАТ } \\
\text { «Дніп- } \\
\text { рова- } \\
\text { гон- } \\
\text { маш» }\end{array}$ & $\begin{array}{c}\text { Напів- } \\
\text { вагон } \\
\text { ТОВ } \\
\text { «Со- } \\
\text { фія-Ін- } \\
\text { вест» }\end{array}$ & $\begin{array}{c}\text { Напів- } \\
\text { вагон } \\
\text { ПАТ } \\
\text { «Азов- } \\
\text { маш» }\end{array}$ & $\begin{array}{c}\text { Вагон- } \\
\text { цис- } \\
\text { терна } \\
\text { ПАТ } \\
\text { «Азов- } \\
\text { маш» }\end{array}$ \\
\hline & \multicolumn{8}{|c|}{ Значення параметра } \\
\hline 1 & 2 & 3 & 4 & 5 & 6 & 7 & 8 & 9 \\
\hline $\begin{array}{l}\text { 1. Вантажо- } \\
\text { підйомність, т }\end{array}$ & $\geq 75$ & $\geq 75$ & 77 & $\geq 75,5$ & $\geq 73,5$ & 75 & 77 & 73,5 \\
\hline 2. Маса тари, т & 24 & 24 & 23 & 24,5 & 24 & 24,5 & 23 & 26 \\
\hline $\begin{array}{l}\text { 3. Максималь- } \\
\text { не розрахунко- } \\
\text { ве наванта- } \\
\text { ження від } \\
\text { колісної пари } \\
\text { на рейку, кН }\end{array}$ & 245,25 & 245 & 245,25 & 245,25 & 2452,5 & 245,25 & 245,25 & 245 \\
\hline $\begin{array}{l}\text { 4. Об'єм } \\
\text { кузова, м }\end{array}$ & 90 & 116 & 90 & 90 & 90 & 90 & 95 & 86,5 \\
\hline $\begin{array}{l}\text { 5. Довжина по } \\
\text { осях зчеплен- } \\
\text { ня, мм }\end{array}$ & 13920 & 14720 & 13920 & 13930 & 13920 & 13920 & 13920 & 12020 \\
\hline $\begin{array}{l}\text { 6. Габарит за } \\
\text { ГОСТ } 9238\end{array}$ & $1-\mathrm{BM}$ & $1-\mathrm{BM}$ & 1-BM & $1-B M$ & $1-\mathrm{T}$ & $1-\mathrm{BM}$ & $1-\mathrm{T}$ & $1-B M$ \\
\hline $\begin{array}{l}\text { 7. Конструк- } \\
\text { ційна швид- } \\
\text { кість, км/год }\end{array}$ & 120 & 120 & 120 & 120 & 120 & 120 & 120 & 120 \\
\hline
\end{tabular}

Сьогодні частина перелічених напрямків виконана повністю або частково.

Промисловістю України досягнуті значні успіхи в плані розвитку та освоєння конструкцій пасажирських вагонів.
Вимогами загального характеру для всіх типів пасажирських вагонів передбачалось:

- створення вагонів у габариті 1-ВМ;

- довжина кузова - 26100 мм, база 19000; 
- швидкість руху - від 160 до 200 км/год;

- коефіцієнт плавності руху - не вище 2,8

- мінімальний термін служби - 30 років, 3 кузовом із нержавіючої сталі 40 років;

- міжремонтний пробіг - 450000 км до першого деповського, а потім до 900000 км.
На сьогоднішній день ПАТ «Крюківський вагонобудівний завод» створено ряд пасажирських поїздів 3 технічними характеристиками, що перевищують за своїм рівнем наведені вимоги та характеристики ВАТ «Тверський вагонобудівний завод» (далі ВАТ «ТВЗ»).

Технічні характеристики окремих типів пасажирських вагонів виробництва ПАТ «КВБ» та ВАТ «ТВЗ» наведено в табл. 2.

Таблиця 2

\begin{tabular}{|c|c|c|c|c|c|c|c|c|}
\hline $\begin{array}{l}\text { Найменування } \\
\text { показника } \\
\text { та розмірність }\end{array}$ & 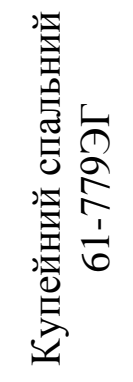 & 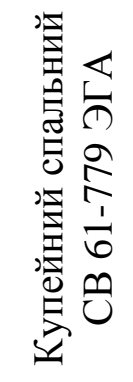 & 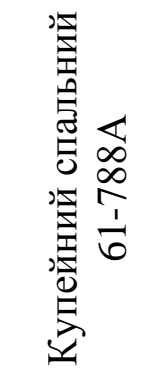 & 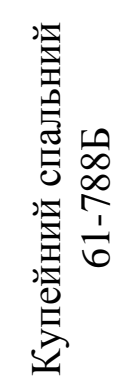 & 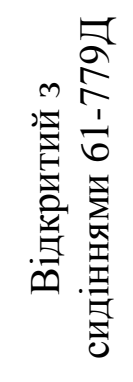 & 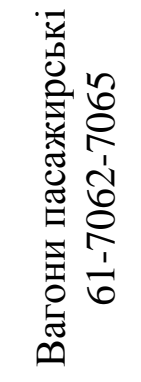 & 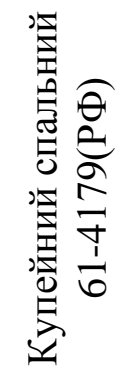 & 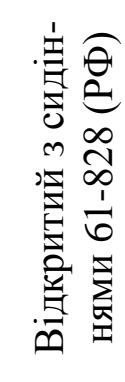 \\
\hline 1 & 2 & 3 & 4 & 5 & 6 & 7 & 8 & 9 \\
\hline $\begin{array}{l}\text { Довжина вагона } \\
\text { по осях } \\
\text { автозчепу, мм } \\
\end{array}$ & 25696 & 26696 & 26696 & 26696 & 26696 & 26696 & 24536 & 24536 \\
\hline $\begin{array}{l}\text { Ширина кузова, } \\
\text { мм }\end{array}$ & 3021 & 3021 & 3021 & 3021 & 3021 & 3420 & 3105 & 3105 \\
\hline $\begin{array}{l}\text { Конструктивна } \\
\text { швидкість, } \\
\text { км/год } \\
\end{array}$ & 160 & 160 & 160 & 160 & 160 & $\begin{array}{l}160 / \\
200\end{array}$ & 160 & 160 \\
\hline Маса тари & 59 & 59 & 59 & 59 & 59 & 55 & 56,7 & 50,3 \\
\hline Кількість купе & 10 & 10 & 9 & 9 & немає & немає & 9 & немає \\
\hline Кількість місць & 40 & 20 & 36 & 18 & 68 & $60-112$ & 36 & 60 \\
\hline Тип візка & $\begin{array}{c}68- \\
7007 / \\
(13)\end{array}$ & $\begin{array}{c}68- \\
7007 \\
(13)\end{array}$ & $\begin{array}{c}68- \\
7007 / 13\end{array}$ & $\begin{array}{c}68- \\
7007 / \\
7013\end{array}$ & $\begin{array}{c}68- \\
4065 / \\
4066\end{array}$ & & $\begin{array}{c}68- \\
4065 / \\
4066\end{array}$ & $\begin{array}{c}68- \\
875 / \\
876\end{array}$ \\
\hline Плавність руху & 2,8 & 2,8 & 2,8 & 2,8 & 3,0 & 2,8 & 3,1 & 3,1 \\
\hline Термін служби & 30 & 30 & 30 & 30 & 30 & 50 & 28 & 28 \\
\hline
\end{tabular}

Як видно 3 табл. 2, технічні характеристики вагонів ПАТ «КВБЗ» переважають аналогічні показники вагонів виробництва ВАТ «ТВЗ».
Сьогодні на ПАТ «КВБЗ» створено двосистемний електропоїзд, що може розвивати швидкість до 200 км/год і більше. Основні технічні характеристики цього поїзда наведено в табл. 3 [4]. 
Таблиця 3

\begin{tabular}{|c|c|c|c|c|c|}
\hline \multirow[t]{2}{*}{ Найменування параметрів, розмірність } & \multicolumn{5}{|c|}{$\begin{array}{c}\text { Нормативні значення для моделей вагонів } \\
\text { поїзда }\end{array}$} \\
\hline & $62-7066$ & $62-7067$ & $62-7068$ & $62-7069$ & $62-7070$ \\
\hline Кількість вагонів у поїзді, шт. & 2 & 2 & 3 & 1 & 1 \\
\hline Маса тари, т & 80 & & & & \\
\hline Маса поїзда, т & \multicolumn{5}{|c|}{560} \\
\hline Питома матеріалоємність вагона, т/місце & 4 & 0,859 & 0,585 & 1,1 & 0,491 \\
\hline Довжина вагона, мм & \multicolumn{5}{|c|}{26696} \\
\hline База вагона, мм & \multicolumn{5}{|c|}{19000} \\
\hline База візка, мм & \multicolumn{5}{|c|}{2560} \\
\hline Габарит & \multicolumn{5}{|c|}{$\mathrm{T}$} \\
\hline Конструктивна швидкість, км/год & \multicolumn{5}{|c|}{$160 / 200$} \\
\hline Плавність руху & \multicolumn{5}{|c|}{ 2,8 (норма) 2,3 (фактично) } \\
\hline $\begin{array}{l}\text { Загальна чисельність пасажирських } \\
\text { місць, } 3 \text { них: }\end{array}$ & 20 & 64 & 94 & 47 & 112 \\
\hline місць бізнес-класу & - & 64 & - & - & - \\
\hline місць економ-класу & 20 & - & 94 & 45 & - \\
\hline $\begin{array}{l}\text { місць для перевезення пасажирів- } \\
\text { інвалідів у колясках }\end{array}$ & - & - & - & 2 & - \\
\hline \multicolumn{6}{|l|}{ Привод: } \\
\hline тип кріплення & \multicolumn{5}{|c|}{ Опорно-рамне } \\
\hline потужність (тривала), кВт & \multicolumn{5}{|c|}{$500-550$} \\
\hline передавальне відношення & \multicolumn{5}{|c|}{4,8309} \\
\hline Гальмо & \multicolumn{5}{|c|}{ Дискове } \\
\hline
\end{tabular}

Актуальною залишається проблема оновлення локомотивного парку, при цьому в першу чергу необхідно вирішувати питання щодо створення сучасних електровозів подвійного живлення. Найближчим часом необхідно виконати у повному обсязі заходи, зазначені в Постанові КМУ від 01.08.11 p. № 840 [5], щодо планів оновлення парку локомотивів у період до 2016 p. Згідно 3 цією програмою до 2016 p. необхідно буде придбати 509 одиниць тягового рухомого складу. Станом на 01.01.12 p. передбачалось списати близько $80 \%$ електропоїздів і 93 \% дизель-поїздів.

Стратегічним напрямком розвитку транспорту $\epsilon$ також мультимодальні перевезення. Цей вид перевезень $\epsilon$ важливим як для внутрішніх вантажних перевезень, так і для міжнародних. Основна роль тут відводиться контрейлерним перевезенням. Слід зазначити, що контрейлерні перевезення дорожчі від перевезення вантажів у контейнерах, але в перспективі вони будуть складати серйозну конкуренцію іншим видам залізничних вантажних перевезень. Разом 3 тим розвитку контрейлерних $\mathrm{i}$ контейнерних перевезень необхідно приділяти належну увагу, оскільки майбутне саме за цим видом ватажних перевезень.

Застосування

перспективних конструкційних матеріалів для виробництва сучасних локомотивів i вагонів $є$ одним 3 визначальних факторів підвищення вантажопідйомності, надійності, терміну служби та міжремонтних періодів експлуатації, а 
також зменшення експлуатаційних витрат на утримання рухомого складу.

Стратегічними напрямками в галузі створення і освоєння нових марок сталей для виробництва рухомого складу слід вважати такі:

- створення литих і прокатних сталей 3 підвищеною втомною міцністю, високою експлуатаційною надійністю, а для елементів візків зі зносостійкістю та коефіцієнтом запасу на втому не менше 2,0;

- створення металопрокату підвищеної міцності (клас міцності не нижче 450) і корозійної стійкості з метою збільшення терміну служби та підвищення маси тари вантажних вагонів без збільшення маси тари;

- розроблення та освоєння виробництва економно легованих нержавіючих сталей підвищеної міцності.

Для створення конструкцій вагонів нового покоління, підвищення їх міцнісних показників, зокрема втомної міцності, пропонується створення економічних конструкційних сталей 3 необхідними міцнісними характеристиками (гарантованим класом міцності 420) 3 використанням азотних лігатур на базі феросплавів та отримання прокату підвищеної міцності на металургійних підприємствах України. Прокат із карбонітридним зміцненням призначається для виготовлення вантажних вагонів нового покоління, які повинні мати підвищену міцність i корозійну стійкість. Прокат повинен бути розрахований на використання в галузі вагонобудування в межах країн СНД без обмежень.

У подальшому необхідно продовжити дослідження 3 використання бейтонітних сталей і суперсплавів на основі нікелю або нікелю і заліза. Останні дослідження дозволять підвищити надійність і якість коліс і рейок, що є головними складовими у комплексі забезпечення безпечної експлуатації рухомого складу залізниць, і підвищити в декілька разів довговічність коліс i рейок, підвищити на 15-20\% контактно-втомлену міцність і зменшити на 20-30\% опір їх зносу.

Стратегічним напрямком $\epsilon$ продовження робіт щодо освоєння матеріалів для локомотивобудування, виробництва пасажирських вагонів i моторвагонного рухомого складу, передусім пасажирського парку, а саме вироби складного геометричного поперечного профілю, облицювальні панелі опорядження салонів, каркасні елементи крісел, підлокітників, столиків тощо, вентиляційні решітки, елементи опорядження душових модулів і туалетів, лотки кабельних трас, елементи монтажу трубопроводів, щільникові панелі, оглядові люки, панелі-розсіювачі люмінесцентного освітлення, матеріали для створення металопластикових композицій i металоармованих конструкцій тощо. Специфічні вимоги - екологічна, санітарногігієнічна та пожежна безпека, здатність зберігати властивості мінімум до капітального ремонту рухомого складу, висока механічна міцність, вібраційна стійкість, стійкість до дії світла, пилу та вологи, збереження декоративноестетичних якостей, здатність до безпечної утилізації після закінчення терміну служби.

Стратегічно важливими $є$ напрямки освоєння промислового виробництва визначеної номенклатури довгомірних екструдованих профілів зі складним поперечним перерізом 3 алюмінієвих сплавів; відпрацювання технологій, що дозволяли б перейти до виробництва широкоформатних екструдованих профілів 3 алюмінієвих сплавів для зовнішніх несучих елементів кузовів пасажирських вагонів і вагонів моторвагонного рухомого складу; виробництва вітчизняної імпортнозамінної продукції, створення технологій виробництва склопакетів, а також використання нових технологій у санітарно-гігієнічних модулях, технологій підготовки поверхонь кородуючих металевих матеріалів до склеювання як 3 металевими, так і 3 неметалевими 
матеріалами, а також підготовка до нанесення лакофарбових, гальванічних i полімерних покриттів, технологій нерознімних з'єднань на основі клейових композицій.

На підставі викладеного можна сформулювати стратегічні напрямки щодо забезпечення безпеки на об'єктах залізничного транспорту:

- удосконалення основних положень державної політики та нормативноправової бази забезпечення безпеки інфраструктури залізничного транспорту та їх реалізація;

- розроблення комплексу заходів 3 реалізації положень державної політики та пріоритетних напрямків забезпечення безпеки на залізничному транспорті України;

- визначення негативних явищ безпеки об'єктів залізничної техніки;

- розроблення системних вимог щодо забезпечення безпеки об'єктів інфраструктури залізничного транспорту;

- розроблення методичних, методологічних i практичних методів вирішення завдань щодо забезпечення безпеки функціонування транспортної системи України;

- розроблення переліку критеріїв для поєднання об'єктів залізничного транспорту в групи 3 метою зниження витрат на забезпечення безпеки шляхом типізації та стандартизації;

- розроблення заходів з забезпечення об'єктів інфраструктури залізничного транспорту щодо мобілізаційної готовності на випадок надзвичайних ситуацій;

- розроблення та адаптація новітніх технологій і програмно-апаратних засобів забезпечення безпеки, у тому числі пасивних та активних засобів захисту критично важливих та об'єктів інфраструктури залізничного транспорту, які можуть створити загрозу, створення автоматизованої системи моніторингу стану управління безпекою таких об'єктів.
Стратегічно важливими залишаються питання щодо принципів i механізмів державного регулювання в монопольному, тимчасово монопольному та конкурентному сегментах ринків послуг на залізничному транспорті, що є невід'ємним елементом забезпечення економічної та політичної незалежності держави.

Стратегія розвитку наукових досліджень залізничного транспорту повинна рухатися за такими напрямками:

- розроблення комплексу технічних регламентів, які мають вимоги щодо забезпечення безпеки та охорони навколишнього середовища до об'єктів технічного регулювання на залізничному транспорті;

- розроблення нормативно-методичної бази розрахунків параметрів експлуатаційної готовності, міцності, надійності та безпеки ресурсу рухомого складу та інфраструктури транспортного комплексу залізниць;

- розроблення нових технічних вимог на продукцію та до нормативної бази взаємодії з виробниками (постачальниками) на основі менеджменту управління якістю.

Для цього необхідно в першу чергу передбачити:

1) роботи щодо розроблення математичних моделей розвитку інфраструктури залізничного транспорту;

2) створення нормативної бази збереження та експлуатації об'єктів інфраструктури залізничного транспорту;

3) розроблення комплексних перспективних рішень щодо реконструкції інфраструктури залізниць України для допуску до експлуатації рухомого складу 3 осьовим навантаженням 25 тс;

4) застосування комплексних рішень щодо об'єктів, які рідко обслуговуються, системами автоматики, зв'язку та системами енергозабезпечення;

5) зниження питомих витрат на обслуговування інфраструктури залізничного транспорту понад $20 \%$. 
Параметри управління рухом поїздів 3 одночасним забезпеченням безпеки передбачають виконання таких робіт:

a) управління рухом на основі супутникових технологій та автоматичної ідентифікації рухомого складу;

б) впровадження комп'ютерних систем управління у взаємодії з цифровими радіоканалами;

в) автоматичне управління локомотивами при проведені маневрових робіт;

г) впровадження діагностичних станцій і діагностичних систем у пунктах обслуговування та на межі кінцевих маршрутів; д) забезпечення названих систем програмним забезпеченням у частині безпеки на відповідність міжнародним стандартам.

Стратегічним напрямком є розділення залізниць на окремі колії для перевезення вантажів i пасажирів швидкісним транспортом.

3 метою забезпечення високошвидкісного руху необхідно передбачити системи технічного обслуговування швидкісної та високошвидкісної інфраструктури та рухомого складу шляхом створення відповідних сервісних центрів.

\section{Список літератури}

1. Прейгер, Д.К. Стратегічні напрямки розвитку транспортної галузі України у післякризовий період. Аналітична доповідь [Текст] / Д.К. Прейгер, О.В. Собкевич, О.Ю. Смельянов; Національний інститут стратегічних досліджень. - К., 2011. - 48 с.

2. Комплексна програма оновлення залізничного рухомого складу України на 20082020 роки [Текст]: Затв. наказом Мінтрансзв’язку України 14.10.2008 p., № 1259. - К, 2008.

3. Державна програма розвитку машинобудування на 2008-2011 роки [Текст]: Затв. Постановою Кабінету Міністрів України від 18.04.2006 р., № 516. - К., 2006. - 9 с.

4. Програма оновлення локомотивного парку залізниць України на 2012-2016 pp. [Текст]: Затв. Постановою Кабінету Міністрів України від 01.08.2011 р., № 840. - К., 2011. $2 \mathrm{c}$.

5. Игнатов, Г.С. Межрегиональный двухсистемный электропоезд. ВАТ «Крюківський вагонобудівний завод» [Текст] / Г.С. Игнатов, В.В. Пронин, П.М. Томица [и др.]. Кременчуг, 2012. - 345 с.

Ключові слова: транспорт, рухомий склад, залізнична галузь, машинобудування, стратегія, розвиток.

\section{Анотаціï}

У статті наведено стратегічні напрямки розвитку вітчизняного транспортного машинобудування на перспективу.

В статье приведены стратегические направления развития отечественного транспортного машиностроения на перспективу.

The article presents the strategic approaches for national transport engineering in the future. 